Afr. J. Trad. CAM (2007) 4 (2): 211 - 218

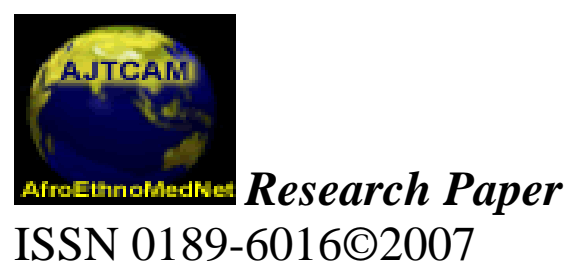
Afr. J. Traditional, Complementary and Alternative Medicines www.africanethnomedicines.net

\title{
ETHNO-MEDICINAL PLANTS AND METHODS USED BY GWANDARA TRIBE OF SABO WUSE IN NIGER STATE, NIGERIA, TO TREAT MENTAL ILLNESS
}

\author{
J. A. Ibrahim*, I. Muazzam, I. A. Jegede, O. F. Kunle, J. I. Okogun \\ Department of Medicinal Plant Research and Traditional Medicine (MPR \& TM) \\ National Institute for Pharmaceutical Research and Development (NIPRD), \\ PMB 21 Garki, Abuja, Nigeria \\ *E-mail: sadiqoyene@yahoo.com
}

\begin{abstract}
The Gwandara people of Sabo Wuse in Niger State, Nigeria are the original inhabitants of Wuse in Abuja Municipal Area Council. They were resettled at this present location of Sabo Wuse from Wuse in the Federal Capital Territory Abuja when the seat of government moved from Lagos to Abuja 30 years ago. Sabo Wuse still remains relatively a remote settlement and their lifestyle unchanged. They still depend to a large extent on their traditional knowledge of medicinal plants to treat ailments. Ethnobotanical survey was conducted to identify and document methods traditionally utilized for treatment of mental illness and to expand the quality and quantity of information for research and development especially in the area of new drug discovery and development. About sixty seven (67) Traditional Medicine Practitioners were interviewed orally with use of questionnaire. From our survey, various methods were found to be used by the traditional medicine practitioners to treat mental illness and associated disorders. These include music, incantations and medicinal plants in various formulations - decoction, powder, infusion - which are administered in various ways like fumigation, inhalation, bathing, steaming and drinking. Eighteen plant species belonging to twelve different families were documented to be included in these therapies. In conclusion, there is an array of plants used locally to treat mental illness and it is recommended that such surveys should be funded and leads for drugs to treat mental illness obtained from such, at the same time documenting our indigenous knowledge.
\end{abstract}

Key words: mental illness, indigenous knowledge, ethno- medicinal plants.

\section{Introduction \\ Indigenous knowledge}

Indigenous knowledge has had a role to play in the understanding of the coexistence of man with fauna and flora over the centuries. In-spite of the great importance of this biological diversity and the amount of attention that is currently being given to traditional medicine at both national and international levels, many countries, particularly in Africa still do not have sufficient data on what biological resources they have, their location and how they may be utilized. Many of these biological diversities are used in local traditional medicine and have been reputed, through experience inherited from one generation to the other, to have useful medicinal activity. $80 \%$ or more of the world's population is estimated to depend primarily on traditional medicine for the treatment of ailments (Cunningham, 1993). As noted by Okafor and Ham (1999), dependence on indigenous plants as medicine is due to unavailability of western medicine or high cost of it. It should also be noted that new medicinal compounds are often derived from species that have been useful as folk or traditional or native medicines for centuries, such as anti-hypertensive drug from Rauwolfia serpertina, anti cancer from Catharantus roseus and antimalarial (Artemisinin) from Artemisia 


\section{Ibrahim et. al., Afr. J. Trad. CAM (2007) 4 (2): 211 - 218}

annua. Several reviews on approaches for selecting plants as candidate for drug discovery have been published (Phillipson \& Anderson, 1989; Kinghorn, 1994; Vlietnick \& Vanden, 1991; Harvey, 2000; Farnsworth, 1988). Information from ethnobotanical survey and subsequently phytochemical screening of such plants have been used in the past and are currently being pursued especially in developing countries as a means to initiate drug discovery efforts (Farnsworth, 1966). According to a survey of scientific literature, isolation of chemical compounds was stimulated by ethnobotanical claims and a total number of 122 compounds were identified; 80\% of these compounds were used for the same or related ethnomedical purposes. These compounds were derived from 94 plants species (Farnsworth et. al, 1985).

The problem being encountered currently in Nigeria and other developing countries is that, the people that hold this indigenous knowledge on the uses of plants are the older generation and the traditional healers. However, these custodians are decreasing in number due to death and other unforeseen occurrences. The younger generations have little interest in the practice due to urbanization and technological advancement. Hence there is a danger that this knowledge will eventually disappear if nothing is done. Secrecy, superstition and lack of adequate records on the use of herbal medicine have also led to loss of invaluable heritage in herbal medicine. Treatment of mental illness is one of such area where documentation of how it is being treated is important, because it is an ailment that is hard to diagnose due to their subjectivity. The most bizarre and strange behaviour can often make sense, once it is understood why the person is thinking and feeling that way.

\section{Mental illness}

Mental Illness is a disorder characterized by disturbances in a person's thoughts, emotions, or behavior. The term mental illness can refer to a wide variety of disorders, ranging from those that cause mild distress to those that severely impair a person's ability to function. Many behaviors are recognized throughout the world as being indicative of mental illness. These include extreme social withdrawal, violence to oneself, hallucinations (false sensory perceptions), and delusions (fixed, false ideas). Mental illness creates enormous social and economic costs (Encarta, 2006).

\section{Objectives}

Currently, there is a shift towards natural or traditional medicine due to the high prescription costs and high incidence of adverse effects and resistance associated with these orthodox medicines. As it is, traditional medicines are more readily available, cheap and because they are said to be 'natural' have less adverse effects on the patient. The ethnobotanical plants of Sabo Wuse are reported for the first time. The aims and objectives of this work are:-

$>$ To conduct a comprehensive investigation of methods and ways of treating mental illness in Sabo Wuse.

$>$ To identify and document plants traditionally utilized for the treatment of mental illness in the area.

$>$ To investigate the importance of medicinal plants to the local people, their availability and endangeredness.

$>$ Finally, to expand the quality and quantity of information available for research and development especially in the area of new drug discovery and development.

\section{Study Area}

Sabo Wuse is a resettlement Town in Tafa LGA in Niger State, Nigeria, about 65KM from the urban settlement of Abuja. The inhabitants of Sabo Wuse are the original inhabitants of Wuse in Abuja Municipal Area council in the Federal Capital Territory, Abuja. They were resettled at this present location in Niger State when the seat of government moved from Lagos to Abuja 30 years ago. Their main language is Gwandara. Sabo Wuse still remains a relatively remote settlement and the lifestyle of the inhabitants is more or less unchanged despite their proximity to the urban settlement of Abuja. Their main economic base also still remains intensive subsistence agriculture which is exclusively non-mechanized and human labour-based. Although, the village has electricity, it does not have pipe-borne water and good road network. The people still depend to some extent on their traditional knowledge of medicinal plants to treat ailments despite the presence of a village health center. 
Ibrahim et. al., Afr. J. Trad. CAM (2007) 4 (2): 211 - 218

\section{Research Methodology}

The data presented here is drawn from an ethnobiological survey using questionnaire and oral interview conducted at Sabo Wuse on the lifestyle of the people, plants and animals used as food, medicine and source of livelihood. Participatory approach was used in which the local people and traditional healers contributed their knowledge acquired over time on the uses of plants and animals as food, medicine and generally on their lifestyle. Prior informed consent was used in this survey.

Preliminary visits were done to familiarize with the place and also collection of plant specimens found in the area for identification and authentification in the herbarium. An introduction letter from the sponsoring institute (National Institute for Pharmaceutical Research and Development, Abuja) was submitted at the Local Government (LG) Secretariat. The team was introduced by the Director of the Primary Health Care in the LG to the Chairman and Secretary of the Herbal Healers Association of Tafa LGA. The Secretary of the Association in turn provided a list of the traditional healers in the area and formal introductions were done appropriately. Subsequently, appointments were booked with traditional healers individually for the proper interview. The survey was carried out over a period of 12 months (March 2005 to February 2006).

Relevant information on the ways and methods used in treating mental illness were obtained through the use of oral interview. About 67 traditional healers were interviewed. Plant specimens were authenticated at the herbarium of National Institute for Pharmaceutical Research and Development, Abuja. Voucher specimens were also deposited at the same herbarium. Reference to authentic published data in the area of secondary metabolites was also carried out.

\section{Results \\ Causes of Mental Illness}

Any study of the life style of people will make little or no sense at all unless we understand why some people behave differently from others. We need to understand not only what they practice and how they practice it, but also what makes them believe in such practices. In this wise, the traditional conception of diseases is not simply the result of dysfunction or a lesion in an organ whether spontaneous or provoked by some material cause but essentially a rupture in the harmony of life which is attributed to both material and immaterial world. Therefore, mental illness is not only of organic physiopathological cause, but together with this, there are non-organic causes, those due to supernatural forces referred to as spirits and require both an organic and cosmic type of treatment to be administered jointly or separately.

Spirits are called 'Mutanen boye' (Hausa language), that is the 'the Hidden Ones or Hidden People'. According to the locals they are creatures that assume any shape and they pose great fear among the people because it is believed that the bad ones or the wicked ones can cause serious harm to humans and the remedy for this harm is usually very cumbersome, involving a lot of processes e.g. music, fumigations, incantations, inhaling of some prepared powdered stuff and some kind of magico-religious combination of therapeutic regimen.

\section{Custodians of Knowledge}

From the interview conducted, the respondents were found to be mostly in the age group of 60 years and above (43\%). The active age group, (between the ages of 20 to 40 years) is very few (2\% \& 6\%).Table 1.

\section{Methods of treating mental illness}

are:

Different methods were found to be used by the traditional healers for the treatment of this illness. These

Girka: - is a type of music where praises were sung to please the spirit in order for it to leave the patient. The kind of instrument used for this purpose is called 'Gurmi' or 'Garaya'. It is a locally made one-string guitar.

Bori: - This is another way of relieving the patient of the problem by seeking the consent of spirits for permission to treats the patient.

Incantations: - Incantation are words, chants or rhythms believed to have influence or power over other people, spirits or supernatural being. 
Ibrahim et. al., Afr. J. Trad. CAM (2007) 4 (2): 211 - 218

Table 1: Percentage of Respondents (Traditional Healers) at Sabo Wuse in Niger state of Nigeria according to their Age Group

\begin{tabular}{|l|l|l|}
\hline Age group (Years) & Number of Respondents & Percentage of Respondents \\
\hline $20-29$ & 1 & $2 \%$ \\
\hline $30-39$ & 4 & $6 \%$ \\
\hline $40-49$ & 19 & $28 \%$ \\
\hline $50-59$ & 14 & $21 \%$ \\
\hline $60-$ Above & 29 & $43 \%$ \\
\hline
\end{tabular}

Medicinal Plants: - In this survey about eighteen (18) plant specimens belonging to 10 families were found to be used in the treatment of this ailment (Table 2). These plants have been collected, identified and deposited in the Institute's Herbarium. The remedies were found to be prepared in various ways, either in form of decoction, infusion or powder and they were also administered in various way; inhalation/sniffing, drinking of decoction and infusion, steaming and bathing of the patient with either the decoction or infusion and fumigation. These plants are either used alone or in combination with other plants. Patients with Mental illness are either treated with one of these method or combination of methods.

\section{Discussion}

In this survey, it was discovered that there is little or no replacement in the practice by the younger generations, therefore, the custodians of this traditional knowledge are, and still remain the older generations. The percentage of respondents between the age group of 60years and above is $43 \%$ while the younger and active age group of $20-40 y e a r s$ is just $8 \%$ of the total respondents. There is a great need to create awareness and also incentive to encourage the younger generations to undertake such an area of study that is so important to socialeconomic life of the indigenes since the older generations are seriously decreasing in number due to death.

It is important to understand the causes of mental illness from the perspective of the locals, that way one will be able to understand and appreciate their choice of methods of treating this ailment. The indigenes of Sabo Wuse hardly take any of their patients with mental illness to a western hospital. The dependence of the Sabo Wuse community or any other rural community in Nigeria on traditional healers for the treatment of people suffering from mental illness in particular is largely influenced by their belief that this ailment is caused by 'beings' of the supernatural world and therefore, supernatural solution is needed. The issue of low income, high cost of modern medical facilities e.t.c is not important when it comes to taking a decision on where to take a patient with mental illness.

The rationale for selecting Bori, Girka and Incantations as methods employed by the practitioners to treat this ailment is influenced by their belief that the ailment is caused by bad spirits or beings of the supernatural world, which cause disharmony in the patients' life. Therefore, these methods which have to do with appeasing or conversing with spirits are used. Incantations involve using words that are supposed to be understood by the spirits concerned. The Girka music is employed to please or displease the spirit in order for it to leave the patient. The Bori is also a way of exorcising the spirit from the patient.

The Bori, Incantation and Girka are methods which have been used since time immemorial by most communities and villages in Africa, Asia and even Native American (Sofowora, 1982; Lewis, 2005) to bring relief to people suffering from mental illness or any other ailment. Although, it is still very difficult to determine how these methods work, the fact still remains that most of the patients get relief. The benefit of these types of treatment to the locals cannot be overlooked. The violent patients become calm and quiet or even asleep. The methods give the patient either complete recovery or partial recovery with few intermittent relapses, thus affording the patient the opportunity to live a normal life reducing the pain, anxiety and even economic stress caused by the ailment on the 
Table 2:- Plants used for the treatment of mental illness by the Gwandaras of Sabo Wuse in Niger State of Nigeria.

\begin{tabular}{|c|c|c|c|c|c|c|}
\hline $\begin{array}{l}\text { Scientific } \\
\text { Name/Voucher } \\
\text { numbers } \\
\end{array}$ & Family & Local Name & $\begin{array}{l}\text { Plant } \\
\text { part used }\end{array}$ & $\begin{array}{l}\text { Other } \\
\text { additives }\end{array}$ & Preparation and Administration & Chemical constituents \\
\hline $\begin{array}{l}\text { Milicia excelsa (Welw.) } \\
\text { C.C. } \\
\text { NIPRDH/5918 }\end{array}$ & Moraceae & $\begin{array}{l}\text { Loko, } \\
\text { Roko }^{\mathrm{H}}\end{array}$ & Stem bark & $\begin{array}{l}\text { Sorghum sp or } \\
\text { Millet(Pennice } \\
\text { tum sp) }\end{array}$ & $\begin{array}{l}\text { Powderised the plants together and } \\
\text { infused in water and drink. Or } \\
\text { sprinkle powder on soup to calm } \\
\text { patient }\end{array}$ & \\
\hline $\begin{array}{l}\text { Annona senegalensis } \\
\text { Pers NIPRDH/5919 }\end{array}$ & Annonaceae & $\begin{array}{l}\text { Gwandar } \\
\text { daji }^{\mathrm{H}}\end{array}$ & Root & $\begin{array}{l}\text { Urishi } \\
\text { stembark }\end{array}$ & $\begin{array}{l}\text { Decoction is taken and bath with } \\
\text { once daily. }\end{array}$ & Alkaloids: Anonaine ${ }^{16}$ \\
\hline & & urishi $^{\mathrm{F}}$ & Stem bark & $\begin{array}{l}\text { Annona } \\
\text { senegalensis } \\
\text { stembark }\end{array}$ & $\begin{array}{l}\text { The decoction is taken and also } \\
\text { bath with it by the patient }\end{array}$ & \\
\hline $\begin{array}{l}\text { Securidaca } \\
\text { longepedunculata Fres. } \\
\text { NIPRDH/5920 }\end{array}$ & Polygalaceae & $\begin{array}{l}\text { Sanya, } \\
\text { uwar- } \\
\text { mgunguna }\end{array}$ & Root & & & $\begin{array}{l}\text { Mythyl ester: } \\
\text { Mythylsalicylate, } \\
\text { Saponnin (Lognay et.al, } \\
\text { 2000). Tannins, mucilage } \\
\text { (Dalziel, 1948). }\end{array}$ \\
\hline $\begin{array}{lr}\text { Acaccia } & \text { macrothyrsa } \\
\text { Harms. } & \text { NIPRDH/5921 }\end{array}$ & $\begin{array}{l}\text { Fabaceae. } \\
\text { Subfam. } \\
\text { Mimosoideae }\end{array}$ & Gwano & Stem & Root of sanya & Not disclosed & \\
\hline $\begin{array}{l}\text { Tamarindus indica } \\
\text { Linn. } \quad \text { NIPRDH/5922 }\end{array}$ & $\begin{array}{l}\text { Fabaceae. } \\
\text { Subfam. } \\
\text { ceasalpinoideae }\end{array}$ & Tsamiya & $\begin{array}{l}\text { Stembark } \\
\text { \& Root. }\end{array}$ & $\begin{array}{l}\text { Pap (maize or } \\
\text { Guinea corn } \\
\text { gruel) }\end{array}$ & $\begin{array}{l}\text { Decoction of both the root \& } \\
\text { stembark used to make pap \& to be } \\
\text { taken daily. }\end{array}$ & \\
\hline $\begin{array}{l}\text { Lantana camara Linn. } \\
\text { NIPRDH/5797 }\end{array}$ & Verbanaceae & $\begin{array}{l}\text { Kimbar } \\
\text { maharba }\end{array}$ & $\begin{array}{l}\text { Whole } \\
\text { plant }\end{array}$ & & $\begin{array}{l}\text { Powderised the plant and use it to } \\
\text { fumigate the patient. }\end{array}$ & $\begin{array}{l}\text { Volatile oil: } \\
\text { Monoterpenoid, } \\
\text { Triterpenoids, } \\
\text { Sesquiterpenoids( Abdel- } \\
\text { Hardy, 2005; Begun et. al, } \\
\text { 2000). }\end{array}$ \\
\hline $\begin{array}{l}\text { Ximenia Americana } \\
\text { Linn. NIPRDH/5774 }\end{array}$ & Olacaceae & Tsada & $\begin{array}{l}\text { Stem } \\
\text { bark, root } \\
\text { \& leaves }\end{array}$ & & $\begin{array}{l}\text { Decoction to be taken } 3 \text { times } \\
\text { daily. }\end{array}$ & $\begin{array}{l}\text { Saponins, Cyanogenic } \\
\text { glycosides, } \\
\text { Flavoniods,Tannins ( } \\
\text { Ogunleye \& Ibitoye, } \\
\text { 2003). }\end{array}$ \\
\hline & & wirshi & Stembark & $\begin{array}{l}\text { Root of sanya } \\
\text { ( Securidaca } \\
\text { longepeduncul } \\
\text { ata) }\end{array}$ & $\begin{array}{l}\text { Powderised for inhalation by the } \\
\text { patient. Also infused for the patient } \\
\text { to drink and bath with it. }\end{array}$ & \\
\hline
\end{tabular}




\begin{tabular}{|c|c|c|c|c|c|c|}
\hline $\begin{array}{ll}\text { Eleusine } & \text { indica } \\
\text { NIPRDH/5923 } & \\
\end{array}$ & Poaceae & Tuji & $\begin{array}{l}\text { Whole } \\
\text { plant }\end{array}$ & & $\begin{array}{l}\text { The plant is burn to fumigate the } \\
\text { patient. }\end{array}$ & $\begin{array}{l}\text { Flavonoids (Hilu et. al, } \\
\text { 1978). }\end{array}$ \\
\hline $\begin{array}{l}\text { Lophira alata Banks } \\
\text { ex. Gaertn.f. } \\
\text { NIPRDH/5812 }\end{array}$ & Ochnaceae & Kujeme & stembark & & & \\
\hline $\begin{array}{l}\text { Afzelia Africana Smith } \\
\text { NIPRDH/5924 }\end{array}$ & $\begin{array}{l}\text { Fabaceae. } \\
\text { Subfam. } \\
\text { ceasalpinoideae }\end{array}$ & Kawo & Stembark & $\begin{array}{l}\text { Stembark of } \\
\text { Lophira alata }\end{array}$ & $\begin{array}{l}\text { Fresh stembark of L. alata \& } \\
\text { A.africana are powdered together } \\
\text { \& later dried. It is infused in water } \\
\text { for } 2 \mathrm{hr} \text {. and given to the patient to } \\
\text { drink \& take bath to sedate him. }\end{array}$ & \\
\hline $\begin{array}{lr}\text { Olax } & \text { subscorpioidea } \\
\text { Oliv. } & \text { NIPRDH/5925 } \\
\end{array}$ & Olacaceae & $\begin{array}{l}\text { Gwano } \\
\text { kurmi }\end{array}$ & $\begin{array}{l}\text { Whole } \\
\text { plant }\end{array}$ & $\begin{array}{l}\text { Eleusine } \\
\text { indica }\end{array}$ & & $\begin{array}{l}\text { Santalbic acid from seed } \\
\text { (Cantell et.al, 2003). }\end{array}$ \\
\hline $\begin{array}{l}\text { Eragrostis celianensis } \\
\text { NIPRDH/5926 }\end{array}$ & Poaceae & $\begin{array}{l}\text { Bunsurun } \\
\text { fage }\end{array}$ & $\begin{array}{l}\text { Whole } \\
\text { plant }\end{array}$ & $\begin{array}{l}\text { Eleusine } \\
\text { indica }\end{array}$ & $\begin{array}{l}\text { O.subscoipioidea, E. indica \& E. } \\
\text { celianensis are made into semi } \\
\text { powder \& burn to fumigate non- } \\
\text { violent mental patient. }\end{array}$ & \\
\hline $\begin{array}{l}\text { Boswellia dalzielii } \\
\text { Hutch. NIPRDH/5927 }\end{array}$ & Burseraceae & Hano & Stembark & & $\begin{array}{l}\text { Infused the powderised stembark } \\
\text { and drink. }\end{array}$ & $\begin{array}{l}\text { Tannins (Nwinyi et.al, } \\
\text { 2004) }\end{array}$ \\
\hline $\begin{array}{l}\text { Hyparrhenia } \\
\text { subplumosa } \\
\text { NIPRDH/5930 }\end{array}$ & Poaceae & $\begin{array}{l}\text { Kiibiyar } \\
\text { maharba }\end{array}$ & $\begin{array}{l}\text { Whole } \\
\text { plant }\end{array}$ & $\begin{array}{l}\text { Antidesma } \\
\text { venosum }\end{array}$ & & \\
\hline $\begin{array}{l}\text { Antidesmar venosum } \\
\text { Tul. NIPRDH/5928 }\end{array}$ & Euphorbiaceae & Kizni & Stem bark & $\begin{array}{l}\text { Hyparrhenia } \\
\text { subplumosa }\end{array}$ & $\begin{array}{l}\text { Both plants are dried \& burn to } \\
\text { fumigate the patient. }\end{array}$ & $\begin{array}{l}\text { Alkaloids;- } \\
\text { Antidesome(Bringmann } \\
\text { et.al, 2000); } \\
\text { saponins,steroids, } \\
\text { terpenes }\end{array}$ \\
\hline $\begin{array}{l}\text { Combretum } \\
\text { micranthum }\end{array}$ G.Don & Combretaceae & Geeza & $\begin{array}{l}\text { Leaves \& } \\
\text { Root }\end{array}$ & & $\begin{array}{l}\text { The leaves are burn to fumigate \& } \\
\text { the decoction of the root is taken } 3 \\
\text { times daily. }\end{array}$ & Alkaloid: Combretine. \\
\hline
\end{tabular}




\section{Ibrahim et. al., Afr. J. Trad. CAM (2007) 4 (2): 211 - 218}

relatives of the patient and the community at large. The Bori and Incantations have been studied by several authors (Murray, 1991; Verger, 1976) and the critics of all these methods can dismiss them because western science has not proved its workability but that still does not prevent its practitioners from believing in them and benefiting from them and also the indigenes will still continue to consult indigenous traditional healers for the treatment of their patients.

Various medicinal plants used in treating this ailment either singly or in combination with other methods play a great role in relieving these patients. One of these, Securidaca longipeduculata is a species worth noting. This particular species feature most in all the information collected from the healers as herbal remedies for mental illness.

The plants used for treatment of mental illness by the Gwandara people are found to have been screened for some chemical constituents. Various chemical constituents like Alkaloids, flavonoids, saponins, taninns, steroids, Terpenes and mythysalicylate have been isolated from the different plants listed. From literature, it is known that some group of secondary metabolites e.g. the Alkaloids and Flavonoids have effect on the human body either as a stimulant or otherwise. The tropane Alkaloids found in the Solanaceace family have stimulating effect on the CNS. The Atropine Alkaloids from Atropa belladonna and cocaine from Erythroxylum coca are CNS stimulant (Wikipedia, 2006; Finley, 1919). It is also important to note that the first pharmaceutical tranquilizer is an Alkaloid, reserpine isolated in 1952, from Rauwolfia serpentina (Kenner \& Requena, 1996).

\section{Conclusion}

In conclusion, with urbanization and loss of ethnic cultures and customs, some of the information especially on ethnomedicine will no doubt disappear. Therefore, there is a strong need for collection and documentation of this knowledge especially in the developing countries. Further work is ongoing to at least ascertain the pharmacological effects of all the plants listed.

\section{Aknowlegments}

We are grateful to the Management of NIPRD who provided the grant for this work. Dr. Abayomi Orishadipe and Mrs. Grace Ugbabe for their contributions. Usman Abubakar for handling and properly drying all the herbarium specimens. And lastly, Hajia Maryam Kolo Ibrahim through whom we first came in contact with Sabo Wuse.

\section{References}

1. Abdel-Hardy, N. M., Abdei-Halim, A. S. and Al-Ghadban, A. M. (2005). Chemical composition and insecticidal activity of the volatile oils of leaves and flowers of Lantana camara L. Cultivated in Egypt. J Egypt Soc Parasitol. 35(2):687-698.

2. Begun, S., Wahab, A., Siddiqui, B. S. and Qamar, F. (2000). Nematicidal constituents of the aerial Parts of Lantana camara. J Nat Prod; 63(6):765-767.

3. Bringmann,.G, J., Schlauer, H. Rischer, M., Wohlfarth, J., Mühlbacher, A., Buske, A., Porzel, J. Schmidt and G. Adam (2000). Revised Structure of Antidesmone, an Unusual Alkaloid from Tropical Antidesma Plants (Euphorbiaceae). Tetrahedron.56 (23); pp. 3691-3695.

4. Cantrell, C. L.; Berhow, M. A.; Phillips, B. S.; Duval, S. M., Weisleder, D., F. and Vaughn, S. (2003). Bioactive crude plant seed extracts from the NCAUR oilseed repository. Phytomedicine, 10(4): 325-333(9)

5. Cunningham, A. B. (1993). Africa Medicinal Plants: Setting priorities at the interface Between conservation and primary health care. People and plant working paper UNESCO

6. Dalziel, J.M. (1948). The useful plants of West Tropical Africa. Crown Agents for the Colonies. London.

7. Finley, Ellingwood (1919). Belladonna. Atropa belladonna. The American Meteria Medica, Therapeutic and Pharmacognosy. Henriettes's Herbal Homepage. www.heriettesherbal.com/eclectic/ellingwood/atropa

8. "Mental Disorders." (2005). Microsoft ${ }^{\circledR}$ Encarta 2006 [DVD]. Microsoft Corporation. 
Ibrahim et. al., Afr. J. Trad. CAM (2007) 4 (2): 211 - 218

9. Farnsworth, N. R. (1988). Screening plants for new medicines. In: Biodiversity (Wilson E. O, ed). Washington DC:National Academy Press,83-97.

10. Farnsworth ,N. R (1966). Biological and Phytochemical screening of plants. J Pharm. Sci 55:225-276

11. Farnsworth N. R, Akerele O, Bingel A S, Soejarto D D, Guo Z (1985). Medicinal plants in therapy. Bull. Wld. Hlth. Org. 63:965-981

12. Harvey A (2000). Strategies for discovering drugs from previously unexplored natural products. Drug Discov Today 5:294-300

13. Hilu. K. W., J. M. J. De Wet and David Seigler (1978). Flavonoid patterns and systematics in Eleusine.Biochem. Systematics Ecol. 6 (3): 247-249.

14. Kenner, Dan; Requena Yves (1996). Botanical Medicine. A European professional perspective. Paradigm publications, Brookline, Massachusetts. pp 4.

15. Kinghorn, A. D. (1994). The discovery of drugs from higher plants. Biotechnology 26:81- 108

16. Last Murray (1991). Spirit Possession as Therapy: Bori among Non-Muslims in Nigeria. Eds. Lewis I M, Ahmed Al-Safi and Sayyid Hurreiz. In: Women's Medicine: the Zar-Bori Cult in Africa and Beyond. Edinburgh University Press. Pp 49-63.

17. Lewis, Claire Elizabeth (2005). "Complementary Medicine." Microsoft ${ }^{\circledR}$ Encarta ${ }^{\circledR} 2006$ [DVD]. Microsoft Corporation,

18. Lognay, G., Marlier, M., Seck and D, Haubruge, E. (2000). The occurrence of 2-hydroxy-6methoxybenzoic acid methyl ester in Securidaca longepeduncula Fresen root bark. Biotechnol. Agron. Soc. Environ. 4(2): 107-110.

19. Nwinyi, F.C; Binda L; Ajoku G A ;Anigu, S O; Enwerem, N. M., Orisadipe, A., Kubmarawa, D. and Gamaniel, K. S. (2004). Evaluation of the aqueous extract of Boswellia dalzielii stembark for antimicrobial activities and gastrointestinal effects. Afri. J.Biotechnol.. 3(5):. $284-288$.

20. Ogunleye. D S; S F. Ibitoye (2003). Studies of antimicrobial activity and chemical constituents of Ximenia Americana Trop. J. Pharmaceu. Res. 2(2): 239-241

21. Okafor, J. C. and Ham, R (1999). Identification, Utilization and Conservation of Medicinal plant in Southeastern Nigeria. Issues in Africa Biodiversity. The Biodiversity support programme, 3: 1-7

22. Phillipson, J. D. and Anderson, L. A. (1989). Ethnopharmacology and Western medicine. J Ethnopharmacol 25: 61-72.

23. Sofowora, A. (1986). Medicinal Plants and Traditional Medicine in Africa. Chichesta: John Wiley and Sons LTD. New York. Pp 8.

24. Verger, P. F. (1976). The Use of Plants in Yoruba Traditional Medicine and its Linguistic Approach: Seminar, October 1976, Department of African Languages and Literature. University of Ife, Nigeria. pp 8.

25. Vlietinck, A. J., and Vanden Berghe, D. A. (1991). Can Ethnopharmacology Contribute to the Development of Antiviral Drugs? J Ethnopharmacol 32:141-153

26. Wikipedia (2006). Solanaceae. (n.d.). Wikipedia, the free encyclopedia. Retrieved September 27, 2006, from Reference.com website: http://www.reference.com/browse/wiki/Solanaceae. 